\title{
Editorial
}

\section{Meeting the challenge of climatic heat stress in construction}

Compared to many industries the construction industry has been slow to meet the challenge of climatic heat stress on its workers. Recent research has provided a greater awareness of the problem and is now guiding solutions. However, a more systematic, holistic approach to climatic heat stress research in construction is needed together with new methodological approaches to research studies.

The strenuous, physical, nature of construction work, typically undertaken in urban areas, and frequently located in regions of the world with high daily temperatures means that climatic heat stress is a common problem for construction workers. Construction workers in Southern USA, the Middle-East, Latin America, Asia and Africa are regularly exposed to extremely high temperatures during long working hours ${ }^{1)}$. The majority of construction workers work in the open, where direct solar radiation puts workers at a high risk of heat related illness. Heat induced illness plus fatigue impairs workers' physical and mental capabilities, reduces worker productivity, but more importantly increases the likelihood of construction accidents and deaths ${ }^{2,3)}$.

Rowlinson et al. identify six key factors that impact climate heat stress: air temperature, humidity, radiant heat, wind speed, the metabolic heat generated by physical activities and the 'clothing effect' that moderates the heat exchange between the body and the environment ${ }^{4}$. These factors contribute to physiological and psychological discomforts that include: dehydration; cramps; heat exhaustion and heat stroke; all of which impact worker performance ${ }^{5,6)}$.

The problems of heat stress are typically addressed by: policies; regulations, recommendations, public and industry education, campaigns and governmental guidelines, limited working hours, and required rest breaks ${ }^{6-9)}$. All these approaches have a role to play but individually or even in combination they cannot be relied upon to make a substantial difference. The danger is that they result in what Yi et al. ${ }^{10)}$ call simply "a list of 'do's and don'ts", a set of principles and best practice that are seldom fully adhered to and seldom rigorously enforced. This reflects the nature of the construction industry which often works in an informal manner with local agreements and local practices ${ }^{11)}$. Many construction workers are migrant workers with limited employment rights and are forced to work at heat stress levels above those permitted by international regulations. The construction industry, driven by productivity and target completion dates is not always recognized for enforcing heat stress regulations. Dutta et al. found that workers on construction sites were fully aware of the problem of heat stress, knew how heat related preventative measures could help overcome the problem but few resources were available to protect these workers. Heat stress levels were frequently higher than those prescribed by international standards. This is not uncommon ${ }^{12)}$.

Rowlinson et al. argue the need to re-engineer the whole safety management systems based on a systems led approach to management safety systems. This they propose should concentrate on the system boundaries of the environmental thresholds that define 'safe work limits' and 'work-rest' regimes. They conclude that "heat stress on construction sites can be handled in three ways: control of environmental heat stress exposure through use of an action triggering threshold system; control of continuous Work Time (CWT) referred by the Maximum Allowable Exposure Duration with mandatory work-rest regimens; enabling self-paced working through empowerment of employees" $"$ ).

To improve the safety management process they propose a simplified system to facilitate effective decisions by front-line supervisors. In an important proposal they suggest a move way from national standards setting out a case for regional standards, that account for the uniqueness of the locality and are derived from 'site based' rather than laboratory based research ${ }^{4}$.

To reduce climatic heat stress in construction the clothing requirements for construction workers demand special 
attention. Clothing worn by construction workers needs to be both protective from the elements and protective from the dangers of construction work. Commonly known as Personal Protective Equipment (PPE), protective clothing for site workers typically includes safety helmets, reflective vests and protective footwear, all of which contribute to 'the clothing effect'. Chan et al. looked at the design of anti-stress clothing for construction workers in the hot and humid weather of Hong Kong. Their findings aligned with Hong Kong Construction Industry Council guidelines ${ }^{13)}$ that recommend that construction workers keep wearing their clothing and wear light colored, loose fitting clothes. Fabrics should be thin, vapor permeable, 'breathable' and have good liquid moisture management and UV protection properties and stressed the importance of both design and fabric considerations. They recommend further research, "particularly in the aspect of optimizing some design and fit features to maximize the design and implementation of new uniforms (for workers) in actual wearing conditions"14).

Could an automated approach to the problem be of benefit? A study by Yi et al. propose an automatic approach through a framework adopting an interactive heat strain and environment evaluation model based on: sensors technologies and mobile communication system; a Bayesian Network of heat strain of workers incorporating the factors of; age, body fat, core temperature, work duration; work intensity; heart rate; and WBGT; and a 3D interpolation model of environment conditions on the work site ${ }^{10)}$.

Whilst welcoming this recent research and other research initiatives to address the problem of climatic heat stress in construction there is need to not only identify and prioritize research topics but to also review the methodological issues relating to heat stress research. In their comprehensive review of heat stress intervention research Yang et al. identified major research gaps and made recommendations for future studies. They also concluded that methodological limitations, such as arbitrary sampling methods and unreliable instruments, could be the major obstacle in undertaking heat stress intervention research and proposed a research framework for conducting heat stress intervention studies in the construction industry. Their research strategy provides researchers and practitioners with a basis for multidisciplinary research and a platform for solving practical problems in the management of heat stress. They emphasize the importance of site studies over experimental work ${ }^{15}$.

Jia et al. argue that researchers should move the focus of their research away from simple interviews, surveys or case studies to re-constructed case studies. They recognize that the issue of heat stress amongst construction workers is not simply a physiological problem, site management problem or organizational problem but one that exists within a wider societal context concluding that safety research would benefit from studying authenticated detailed case studies reconstructed through consideration of the participants input at multiple levels of an organization, third-party observation, physiological data and objective measurement of the work environment and the culture of the business and the community ${ }^{16)}$.

In 2014 Xiang et al. found that workers in the construction industry are one of the groups of workers most likely to be affected by climatic heat stress, secondly only to agricultural workers ${ }^{17}$. With ongoing climate change and the increasing 'heat-island effect' of the inner cities the problems of climatic heat stress amongst construction workers are set to increase. Research initiatives must continue to meet this challenge to help find holistic easily implementable solutions that the industry will adopt.

\section{References}

1) Xiang J, Bi P, Pisaniello D, Hansen A (2014) Health impacts of workplace heat exposure: an epidemiological review. Ind Health 52, 91-101. [Medline] [CrossRef]

2) Chan APC (2012) From heat tolerance time to optimal recovery time- a heat stress model for construction workers in Hong Kong. Presentation at Hong Kong Polytechnic University at 31 May 2012.

3) Tymvios N, Behm M, Jia YA, Johnson K (2016) Heat stress in the U.S. construction industry, June 2016, CIB WBC 2016 Conference, Tempere Finland.

4) Rowlinson S, Yunyanjia A, Li B, Chuanjingju C (2014) Management of climatic heat stress risk in construction: a review of practices, methodologies, and future research. Accid Anal Prev 66, 187-98. [Medline] [CrossRef]

5) Chan APC, Yi W (2016) Heat stress and its impacts on occupational health and performance. Indoor Built Environ 25, 3-5. [CrossRef]

6) CPWR-The Center for Construction Research and Training (2018) Hazard Alert: Heat Stress in Construction. http:// www.elcosh.org/document/2153. Accessed May 29, 2018.

7) NIOSH, The National Institute for Occupational Safety and Health (2018) https:/www.cdc.gov/niosh/topics/heatstress/ default.html. Accessed May 29, 2018.

8) HSE, UK Government Health and Safety Executive (2018) Heat Stress. http://www.hse.gov.uk/temperature/heatstress. Accessed May 29, 2018.

9) Victoria State Government, Australia, Working in Heat (2018) http://www.worksafe.vic.gov.au/pages/forms-andpublications/forms-and-publications/working-in-heat. 
Accessed May 29, 2018.

10) Yi W, Zhu J, Liu X, Wang X, Chan APC (2016) A framework for establishing and early warning system for working in hot environments, 33rd International Symposium on Automation and Robotics in Construction (ISARC 2016).

11) Gillen M, Gittleman JL (2010) Path forward: emerging issues and challenges. J Safety Res 41, 301-6. [Medline] [CrossRef]

12) Dutta P, Rajiva A, Andhare D, Azhar GS, Tiwari A Sheffield P, Ahmedabad Heat and Climate Study Group (2015) Perceived heat stress and health effects on construction workers. Indian J Occup Environ Med 19, 151-8. [Medline] [CrossRef]

13) Hong Kong Construction Industry Council [HKCIC] (2013) Guidelines on safe working in hot weather. http://www. cic.hk/eng/main/aboutcic/news_and_updates/notices_and
announcements/whats_new/Antiheatuniforms/.

14) Chan APC, Guo YP, Wong FKW, Li Y, Sun S, Han X (2016) The development of anti-heat stress clothing for construction workers in hot and humid weather. Ergonomics 59, 479-95. [Medline] [CrossRef]

15) Yang Y, Chan APC (2017) Heat stress intervention research in construction: gaps and recommendations. Ind Health 55, 201-9. [Medline] [CrossRef]

16) Jia AY, Rowlinson S, Loosemore M, Xu M, Li B, Gibb A (2017) Institutions and institutional logics in construction safety management: the case of climatic heat stress. Construct Manag Econ 35, 338-67. [CrossRef]

17) Xiang J, Bi P, Pisaniello D, Hansen A, Sullivan T (2014) Association between high temperature and work-related injuries in Adelaide, South Australia, 2001-2010. Occup Environ Med 71, 246-52. [Medline] [CrossRef]

Li BAIZHAN

Director, National Research Centre for International Collaboration of Low-carbon Green Buildings, P. R. China

Baldwin ANDREW

Co-Director, National Research Centre for International Collaboration of Low-carbon Green Buildings, P. R. China 